\title{
FDG-PET in paraneoplastic neuropathy
}

M.D. Wilkinson, MBChB; M.J. Fulham, FRACP;

R.N.S. Heard, MD, FRCP, FRACP; B.C. McCaughan, FRACS; and S.W. McCarthy, FRCPA

A 54-year-old man presented with a 16-month history of progressive pure sensory neuropathy, ataxia, and weight loss. Neurophysiologic studies revealed normal compound muscle action potentials and motor conduction velocities. Tumor markers and anti-Hu antibodies were not detected, and chest/abdomen CT and bronchoscopy were normal. A whole-body $\left[{ }^{18} \mathrm{~F}\right]$ fluorodeoxyglucose (FDG) PET scan demonstrated a solitary glucose-avid lesion in the right paratracheal lymph node region consistent with a highgrade tumor (figure). PET-guided mediastinoscopy and lymph node biopsy demonstrated a small-cell carcinoma with an associated extensive, noncaseating, sarcoid-like granulomatous reaction. The tumor was strongly positive for cytokeratin, neuron-specific enolase, and Ki-67 (90\% of nuclei).

In this patient, PET was useful in identifying an underlying paraneoplastic syndrome in which conventional investigations were unhelpful. ${ }^{1}$ The associated sarcoid reaction is uncommon, but at least three such cases have been reported in small-cell lung cancer. $^{2}$

1. Rees JH, Hain SF, Johnson MR, et al. The role of $\left[{ }^{18} \mathrm{~F}\right]$ fluoro-2deoxyglucose-PET scanning in the diagnosis of paraneoplastic neurological disorders. Brain 2001;124:2223-2231.

2. Kamiyoshihara M, Hirai T, Kawashima O, Ishikawa S, Morishita Y. Pulmonary small cell carcinoma associated with sarcoid reactions: report of a case. Surg Today 1999;29:382-384.

From the Departments of PET and Nuclear Medicine (Drs. Wilkinson and Fulham), Cardiothoracic Surgery (Dr. McCaughan), and Anatomical Pathology (Dr. McCarthy), Royal Prince Alfred Hospital, Camperdown, Sydney; Department of Medicine (Dr. Fulham), University of Sydney; and Department of Neurology (Dr. Heard), Westmead Hospital, Australia.

Received December 2, 2002. Accepted in final form January 18, 2003.

Address correspondence and reprint requests to Dr. M.J. Fulham, Department of PET and Nuclear Medicine, Royal Prince Alfred Hospital, Bldg. 63, Level A7, Camperdown 2050, Sydney, Australia; e-mail: mfulham@med.usyd.edu.au

A

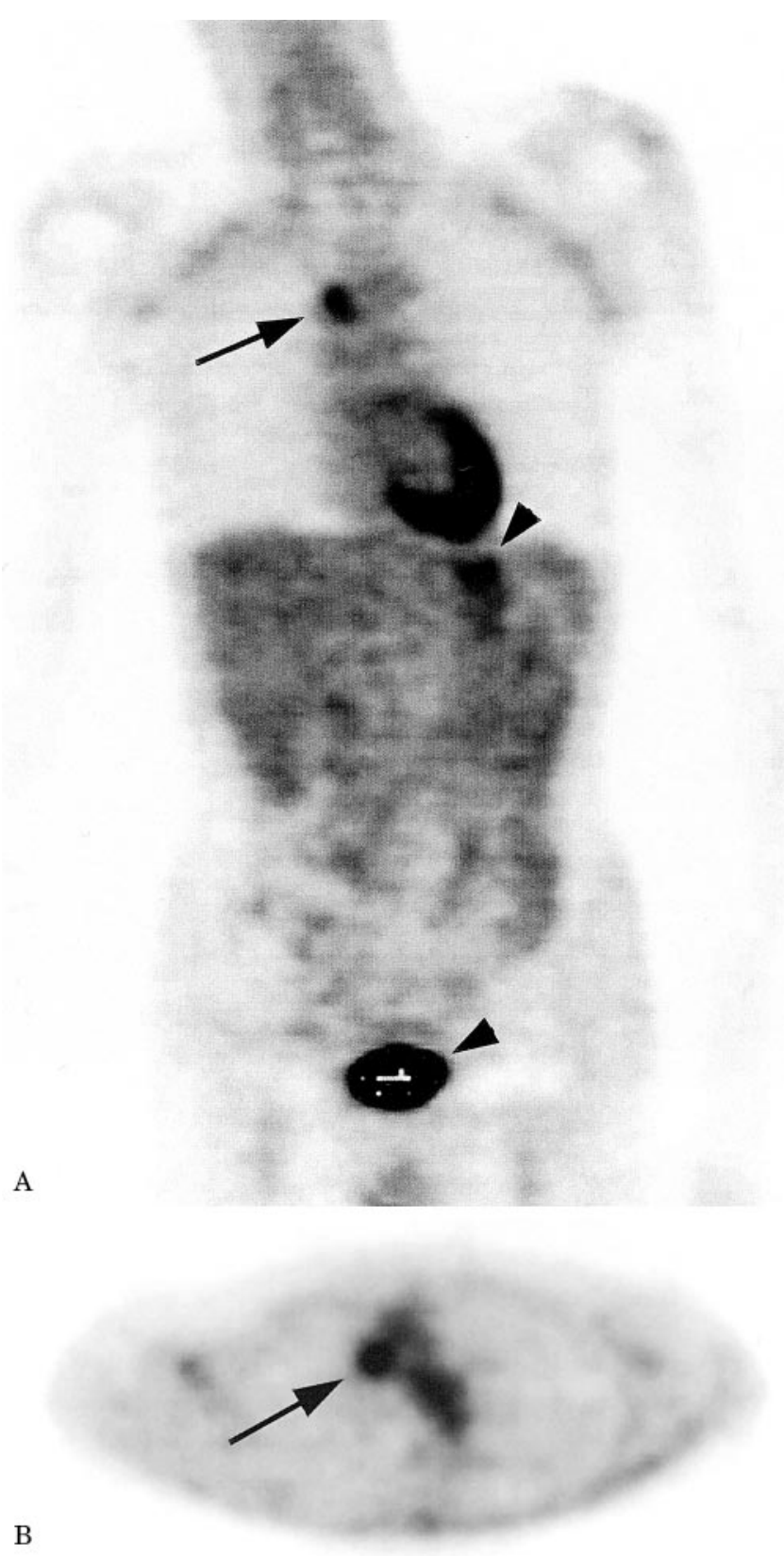

Figure. Attenuation-corrected $\left[{ }^{18} \mathrm{~F}\right]$ fluorodeoxyglucose (FDG) PET images. Coronal (A) and axial (B) images demonstrate a small, rounded, glucose-avid lesion to the right of the midline in the superior mediastinum in the right paratracheal lymph node region (arrows). Both lung fields were otherwise clear. Normal FDG uptake in the stomach and FDG pooling in the bladder are noted (arrowheads). 


\section{Neurology}

FDG-PET in paraneoplastic neuropathy

M. D. Wilkinson, M. J. Fulham, R. N.S. Heard, et al.

Neurology 2003;60;1668

DOI 10.1212/01.WNL.0000059551.48558.6F

This information is current as of May 27, 2003

\section{Updated Information \& Services}

References

Citations

Subspecialty Collections

Permissions \& Licensing

Reprints including high resolution figures, can be found at: http://n.neurology.org/content/60/10/1668.full

This article cites 2 articles, 0 of which you can access for free at: http://n.neurology.org/content/60/10/1668.full\#ref-list-1

This article has been cited by 1 HighWire-hosted articles: http://n.neurology.org/content/60/10/1668.full\#\#otherarticles

This article, along with others on similar topics, appears in the following collection(s):

All Oncology

http://n.neurology.org/cgi/collection/all_oncology

Paraneoplastic syndrome

http://n.neurology.org/cgi/collection/paraneoplastic_syndrome

Peripheral neuropathy

http://n.neurology.org/cgi/collection/peripheral_neuropathy PET

http://n.neurology.org/cgi/collection/pet

Information about reproducing this article in parts (figures,tables) or in its entirety can be found online at:

http://www.neurology.org/about/about_the_journal\#permissions

Information about ordering reprints can be found online:

http://n.neurology.org/subscribers/advertise

Neurology ${ }^{\circledR}$ is the official journal of the American Academy of Neurology. Published continuously since 1951, it is now a weekly with 48 issues per year. Copyright . All rights reserved. Print ISSN: 0028-3878. Online ISSN: 1526-632X.

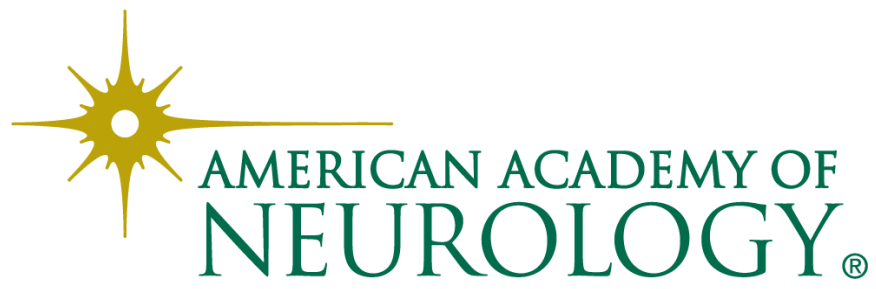

